\title{
To Arm or Not to Arm -- The Divergence of Policy from Opinion on Arming Faculty and Staff on U.S. College Campuses
}

\author{
Rongal D. Watson ", Miriam Guzman, Benjamin Scheel \\ Department of Political Science, Beloit College, Wisconsin, United States
}

Copyright $\bigcirc 2018$ by authors, all rights reserved. Authors agree that this article remains permanently open access under the terms of the Creative Commons Attribution License 4.0 International License

\begin{abstract}
We gauged public opinion concerning firearms on college campuses, specifically whether instructors and staff should be permitted to carry weapons in academic spaces, through a 20-question, online survey of college students, instructors and staff at institutions across the United States from September to November 2016. We performed logistic regression to predict support for arming staff and faculty based on responses. Of 483 respondents, only 26 percent thought instructors and staff members should be armed while working or instructing. Being male, nonwhite and of college age were significant predictors of support for arming faculty and staff. We conclude that despite the spread of "campus carry" legislation, public opinion on college campuses remains overwhelmingly opposed to firearms in academic settings. This suggests a significant disconnect between policymakers pressing for more permissive handgun regulations and those most affected by their decision-making.
\end{abstract}

Keywords Firearms, U.S. Policy, Public Health, Violence

\section{Introduction}

In June 2015, Texas Governor Greg Abbott signed into law Senate Bill 11, permitting individuals legally licensed to do so to carry concealed weapons on university campuses in the state. [1] For one of the authors, news of the bill's passage prompted a classroom debate concerning the potential health hazards of concealed weapons in academic settings. An informal poll of the class revealed an unanticipated level of support for arming staff and faculty members in the classroom and other campus spaces. The authors speculated that the normalization of a more visible security presence following high-profile school shootings and the terrorist attacks of 9/11 may help explain this support. This spurred development of a survey to gauge support for firearms in academic settings among students, staff and faculty members at U.S. colleges and universities. Other scholars investigating this question earlier have found strong opposition both to arming faculty, staff and students and to the presence of concealed weapons on college campuses. [2-3]

In this article, we report the results of our survey. In addition to descriptive characteristics of the respondents, we analyze responses to a key question: "Assuming proper training, should college/university staff members, instructors or professors are permitted to carry a licensed firearm while working/instructing?" Following discussion of the data, we briefly consider the disconnection between public opinion and policy on this important public health concern, as well as directions for future iterations of this survey.

\section{Methods}

To assess opinions concerning firearms on campus, the authors compiled a 20-question online survey of college students, instructors and staff members, using Google Forms. Following Institutional Review Board (IRB) approval, the survey was offered at the authors' home institution and submitted for dissemination to a consortium list serve to which the authors' home institution belongs. Participants were also solicited through one author's network of professional contacts, consisting of government and political science instructors and professors at various institutions nationwide, who were asked to offer the survey via email to course takers and to all students, faculty and staff on their respective campuses. They were also encouraged to forward the survey to colleagues at different institutions. This step added potential respondent pools from college campuses in California, New Mexico, Massachusetts, Colorado, Illinois and Michigan. Due to a commitment to preserving anonymity and the wide target 
audience for survey dispersion (faculty, staff and students at more than 17 colleges and universities nationwide), the exact number of potential respondents is not known. The survey remained open for responses from early September 2016 through to the end of November 2016, garnering a sample of 483 anonymous respondents, 99 of whom were from the authors' home institution.

In addition to descriptive data, we conducted a more formal statistical analysis guided by the following hypotheses:

$\mathrm{H}_{1}$ : Among respondents, those still in college (younger respondents -18 to 23 ) will be more likely to support the arming of college/university staff and instructors, assuming proper training, than older (post-college age -24 and older) respondents.

This hypothesis tests the question that initiated this inquiry - has normalization of the presence of police officers, security guards and other security measures in the post-mass school shooting/post-September 11 world created comfort with armed faculty and staff among more recent high school graduates? Accordingly, we also hypothesized the following:

$\mathrm{H}_{2}$ : Respondents who had police officers, security guards or other security measures at their high schools will show more support for arming properly trained college faculty and staff than those who did not have such measures.

To test these hypotheses, we conducted a logistic regression analysis of yes-no responses to the question, "Assuming proper training, should college/university staff members, instructors or professors be permitted to carry a licensed firearm while working/instructing?" The analysis of this question (the dependent variable) was performed using Stata Statistical Software: Release 12.1 (College Station, TX).

\section{Results}

\section{Demographic, High School and Gun Ownership Data}

In terms of common demographic data, roughly 59 percent of the sample was between the ages of 18 and 23; 37.7 percent held a bachelor's degree or higher; 52.3 percent identified as "female"; and 28.7 percent identified as a race or ethnicity other than "white." And while over 90 percent of respondents were not licensed gun owners, 23.3 percent reported coming from homes in which someone was. The vast majority of the sample, 85.7 percent, reported attending a public high school, with 44.4 percent of respondents having attended high school in the Midwest, 26.5 percent in the western or Pacific states, 16 percent in the northeastern states, and 8.1 percent in the south. The majority of respondents attended suburban high schools (50.9 percent), as opposed to schools in rural (14.1 percent) or urban (35.1 percent) areas. Approximately 39 percent of respondents reported having no security measures of any kind (e.g., police officers, security guards, metal detectors, or combinations thereof) in their high schools.

\section{Guns, Feelings of Safety and Who Should Be Armed}

When presented with the statement, "I feel safer in communities where licensed guns are permitted," 56.2 percent of respondents reported that they "strongly" or "somewhat" disagree. Interestingly, 23.7 percent of respondents answered "Neither agree nor disagree" to this statement. Less ambiguously, nearly 84 percent of respondents either "strongly" or "somewhat" disagreed with the statement, "Licensed gun owners, including students, should be allowed to carry their firearms in academic areas (e.g., classrooms, administrative buildings) on college campuses."

Responses differed somewhat with respect to licensed guns for college/university staff members and faculty in academic settings. While nearly 93 percent of respondents opposed the idea of requiring properly trained staff and faculty members to carry licensed firearms on campus, roughly 26 percent agreed that trained staff and faculty should be allowed to carry their licensed firearms while working on campus. A breakdown of select survey responses specifically from those supporting armed faculty and staff is found in Table 1.

Table 1. Select Responses for Supporters of Armed College Faculty and Staff* (2016)

\begin{tabular}{|c|c|c|}
\hline Survey Question & $\begin{array}{l}\text { Most Common Survey } \\
\text { Response }\end{array}$ & $\begin{array}{l}\text { Percentage of Total Support } \\
\text { Responses }\end{array}$ \\
\hline Age & $18-20$ & $47.97^{+\dagger}$ \\
\hline Current educational attainment & Sophomore & $27.05^{\dagger}$ \\
\hline Gender & Male & $58.2^{\dagger}$ \\
\hline Race/ethnicity & White & 59.68 \\
\hline College/university staff member, instructor or professor & Yes & 75.81 \\
\hline High school environment & Suburban & 49.19 \\
\hline Safety measures in high school & None & 25.81 \\
\hline Legal gun owner & No & 79.84 \\
\hline $\begin{array}{l}\text { Opinion on firearms in academic areas shaped by media coverage of } \\
\text { mass shootings }\end{array}$ & Not at all & 18.55 \\
\hline Total responses (except where noted): 124 & & \\
\hline
\end{tabular}

*Data isolate only respondents responding "yes" to the following survey question: Assuming proper training, should college/university staff, instructors, or professors be permitted to carry a licensed firearm while working/instructing?

†: 122 responses; $†+: 123$ responses 
To be clear, our data suggest that the overwhelming majority of respondents do not support the possession of guns in academic settings by anyone, whether student, faculty or staff. Nevertheless, the significant minority (26 percent) that approved of the carry of licensed firearms by properly trained staff and faculty prompted a closer look at factors that may help to explain this outcome.

Table 2. Logistic Regression of Support for Arming Trained College/University Staff and Faculty, 2016

\begin{tabular}{|c|c|c|c|c|}
\hline $\begin{array}{l}\text { Variable (Reference } \\
\text { category }^{\mathrm{a}} \text { ) }\end{array}$ & $\begin{array}{l}\text { Model } 1(\mathrm{n}=475), \mathrm{OR}^{\mathrm{b}} \\
\left(95 \% \mathrm{CI}^{\mathrm{c}}\right)\end{array}$ & $\begin{array}{c}\text { Model } 2(\mathrm{n}=475), \text { OR } \\
(95 \% \mathrm{CI})\end{array}$ & $\begin{array}{c}\text { Model } 3 \quad(\mathrm{n}=473), \text { OR } \\
(95 \% \mathrm{CI})\end{array}$ & $\begin{array}{c}\text { Latino Model }(\mathrm{n}=473) \text {, } \\
\text { OR }(95 \% \mathrm{CI})\end{array}$ \\
\hline Male & $1.794128 *$ & -- & $1.810386^{*}$ & $1.802362 *$ \\
\hline Nonwhite & $2.195985^{* * *}$ & -- & $1.838081^{*}$ & -- \\
\hline College age & $2.132924 * *$ & -- & $1.817281 *$ & $1.818494 *$ \\
\hline $\mathrm{R}$ is legal gun owner & $4.473489 * * *$ & -- & $4.415546^{* * *}$ & $4.373652 * * *$ \\
\hline $\begin{array}{l}\text { Legal gun owner in R's } \\
\text { household }\end{array}$ & $2.103686^{* *}$ & -- & $2.060422 *$ & $2.031085^{*}$ \\
\hline $\begin{array}{c}\text { High school in } \\
\text { western/Pacific states }\end{array}$ & -- & $1.667512 *$ & 1.318993 & 1.161609 \\
\hline $\begin{array}{l}\text { High school had security } \\
\text { measures }\end{array}$ & -- & $1.936043 * *$ & 1.576205 & 1.517453 \\
\hline Urban high school & -- & .9611095 & -- & -- \\
\hline Public high school & -- & 1.196228 & -- & -- \\
\hline $\mathrm{R}$ is Latino & & & & $2.968934 * * *$ \\
\hline Log likelihood & -236.95886 & -264.00135 & -234.41828 & -231.62314 \\
\hline Pseudo R2 & 0.1209 & 0.0320 & 0.1284 & 0.1388 \\
\hline
\end{tabular}

a: Reference category for binary (dummy) variables. For example, "Male" is coded 1 for male respondents, 0 for all others.

b: Odds ratios

c: Confidence intervals

$* \mathrm{p} \leq 0.05, * * \mathrm{p} \leq 0.01, * * * \mathrm{p} \leq 0.001$

\section{Model 1: Demographic Factors}

The results of the logistic regression analysis are found in Table 2. Of the personal demographic variables captured (Model 1), all had a statistically significant impact on support for properly trained staff and faculty members carrying firearms in academic settings. Male respondents were roughly 79 percent more likely than those identifying as female or other to say "yes" to armed faculty and staff (OR 1.79, 95\% CI 1.14, 2.82). In a somewhat surprising result, respondents identifying with a race or ethnicity other than white were over twice as likely to be in support than their white counterparts (OR 2.20, 95\% CI 1.36, 3.55), while being of college age (18 to 23) resulted in more than twice the level of support for the carrying of licensed firearms by trained staff and faculty than older (24 and older) respondents (OR 2.13, 95\% CI 1.29, 3.53). Legal firearm ownership by the respondent and coming from households with legal gun owners were, unsurprisingly, robust predictors of support.

\section{Model 2: High School Characteristics}

In the second model, we turned to high school characteristics reported by respondents as explanatory factors driving support for armed faculty and staff. However, of the four characteristics captured (high school in the western/Pacific states, presence of security measures, urban high school, and public school), only two west/Pacific region and the presence of security measures, were statistically significant. Specifically, respondents who attended high school in western or Pacific states were roughly 1.7 times more likely than those from other regions to support armed staff and faculty (OR 1.67, 95\% CI 1.06, 2.63), while respondents who had various security measures in school were nearly twice as likely as those who did not to voice support (OR 1.94, 95\% CI 1.21, 3.10).

\section{Model 3: Full Model}

In the full model, we combine the significant variables from the previous two models. As shown in Table 2, being male (OR 1.81, 95\% CI 1.15, 2.86), nonwhite (1.84, 95\% CI 1.10, 3.07), and of college age (OR 1.82, 95\% CI 1.07, 3.09) remain statistically significant predictors of the likelihood of supporting armed faculty and staff in academic settings. Attending high school in western/Pacific states and having reported security measures at one's high school are no longer significant.

\section{Discussion}

Due to our sampling decision, which sought to gain the 
most diverse and geographically dispersed sample pool at the expense of precision with respect to the response rate, we remain cautious in drawing undue conclusions from the results. Despite this limitation, our findings mirror those of earlier studies, and suggest that most respondents across the campuses surveyed oppose the possession of even licensed firearms on their campuses, whether in the hands of students or properly trained staff and faculty. (2-4) There were, however, several noteworthy points that emerged from our analysis. First, while 56.2 percent of respondents either "strongly" or "somewhat" disagree with the statement "I feel safer in communities where licensed guns are permitted," roughly 24 percent of respondents reported that they neither agree nor disagree. This was an unexpectedly large figure and one that raises questions regarding this seeming indifference. One explanation may be that many respondents are from relatively safe communities (roughly 40 percent reported no securities measures in high school), or communities where legal gun ownership is common for hunting or sport shooting rather than for personal safety. Future iterations of the survey may add a question specifically to explore what conditions, environment or other factors, including neighborhood composition and crime rates, may be at work in shaping this opinion.

Second, in the regression analysis, we find mixed support for our hypotheses. As in previous studies, younger respondents appear much more likely than older ones to support more permissive campus policies regarding firearms. Moreover, the relationship between younger age and the policy question we posed, "Assuming proper training, should college/university staff members, instructors or professors be permitted to carry a licensed firearm while working/instructing?" remained robust even in the fully specified regression model, which included other demographic factors such as self-reported gender, region where high school was attended, and households with legal gun ownership. This finding appears to confirm our initial hypothesis $\left(\mathrm{H}_{1}\right)$, which predicted that the younger respondent cohort would be the most supportive of armed faculty and staff. However, our second hypothesis, which reasoned that having attended a high school with security measures would increase the likelihood of approving of armed staff and faculty, was only partially supported. While this variable, together with high school attendance in the western/Pacific states, was statistically significant among the four variables designed to model the high school background of respondents, it failed to remain significant in the fully specified model. The question thus persists of what factors motivate such consistent support among those who think trained faculty and staff should be allowed to carry weapons in academic areas. This is particularly intriguing given the apparent unimportance of media coverage of mass shootings in shaping the opinion of respondents surveyed [see Table 1]. Party affiliation and strength, perceptions of neighborhood and campus crime, and confidence in police (or campus security) stopping crime, all examined by Cavanaugh et al., [3] will be considered for inclusion in future iterations of this survey.

One of the more compelling findings that emerged from the regression analysis, but not hypothesized by the authors, was the consistent support for armed faculty and staff among respondents who identified as a race or ethnicity other than "white" (e.g., Latino, Black/African American, Asian/Pacific Islander). Upon closer examination (see "Latino model" in Table 2), our finding was similar to that of Cavanaugh et al. - among supporters of armed faculty and staff, those who identified as Latino were nearly three times more likely than respondents from other racial or ethnic groups to approve (OR 2.97 CI 1.56, 5.64). Plausible explanations for this tendency are not immediately clear, making this a ripe avenue for further inquiry. Future versions of the survey will disaggregate racial categories (e.g., white, African American) from "Hispanic/Latino" ethnicity to better examine the independent effect, if any, that may be emerging from this ethnic identification. Similarly, we acknowledge that country of origin, rather than a broad ethnic identification with "Hispanic/Latino," might matter more than we assumed for the current survey. Future iterations will attempt to illuminate whether this factor impacts opinion on arming faculty and staff in the U.S. campus context.

\section{Policy Implications}

\section{Disconnect with Public Opinion and Health Effects}

Studies of the impact of public opinion on the actions of Congress and other elected representatives remain divided, with some researchers finding a significant effect for public opinion, others finding responsiveness mainly to the opinions of the wealthy and other defined constituencies, and still others concluding little, if any, connection between public opinion and policy on most issues. [5-9] To the extent that public opinion does matter for the actions of elected representatives, the present study and others like it return identical conclusions: there is no evidence suggestive of broad public support for the loosening of restrictions on the possession of firearms in academic settings, particularly among those most affected by these policies (i.e., college/university students, staff and faculty). Clear majorities of respondents surveyed across different campuses and in different years unequivocally oppose the presence of firearms in academic areas. Yet despite these data, Texas and seven other states have nonetheless enacted laws making the possession of licensed firearms more permissible on campuses nationwide. Nevertheless, in the wake of recent mass school shootings in Parkland, Florida, and Santa Fe, Texas, U.S. President Trump, Texas Lt. Governor Dan Patrick and other lawmakers continue to press publicly for the training and subsequent arming of faculty and staff as a solution for neutralizing an active 
shooter. [10-11] These policies thus represent a tangible disconnect between decision-making by policymakers and public opinion.

At the same time, gun policy in academic settings may have dire implications for general health and safety beyond the possibility of defending against the relatively uncommon phenomenon of campus mass shootings. Recent studies, for example, continue to find evidence of a positive correlation between gun availability and suicide rates. [12] Given the life and academic stresses associated with the college/university experience, the greater availability of handguns could have the unintended consequence of triggering a spike in suicide rates as handguns become more commonplace on college campuses. In this sense, the decision of policymakers across multiple states to enact policies that align with preferences not shared by the vast majority of those most affected, and despite the potential harms such policies could entail, is an area that requires more intensive academic and public scrutiny.

\section{REFERENCES}

[1] Montgomery MFD. Texas lawmakers pass a bill allowing guns at colleges. The New York Times [Internet], 2015 Jun 2. Available from:

https://www.nytimes.com/2015/06/03/us/texas-lawmakersapprove-bill-allowing-guns-on-campus.html.

[2] Patten R, Thomas MO and Wada JC. Packing heat: attitudes regarding concealed weapons on college campuses. Am J Criminal Justice [Internet]. 2012; 38(4):551-569. Available from:

https://link.springer.com/article/10.1007/s12103-012-9191 -1 DOI:10.1007/s12103-012-9191-1

[3] Cavanaugh MR, Bouffard JA, Wells W and Nobles MR. Student attitudes toward concealed handguns on campus at 2 universities. Am J Public Health [Internet]. 2012; 102(12):2245-2247; Available from:

https://www.ncbi.nlm.nih.gov/pmc/articles/PMC3519323/ DOI:10.2105/ajph.2011.300473

[4] Thompson A, Price JH, Dake J and Teeple K. Faculty perceptions and practices regarding carrying concealed handguns on university campuses. J Community Health [Internet]. 2012; 38(2):366-373; Available from: https://lin k.springer.com/article/10.1007\%2Fs10900-012-9626-0 DOI:10.1007/s10900-012-9626-0

[5] Burstein P. The impact of public opinion on public policy: a review and an agenda. Political Res Q [Internet]. 2003; 56(1):29; Available from: https://www.jstor.org/stable/321 9881?seq=1\#page_scan_tab_contents DOI: $10.2307 / 3219881$

[6] Gilens $\mathrm{M}$ and Page BI. Testing theories of American politics: elites, interest groups, and average citizens. Perspective Politics [Internet]. 2014; 12(03):564-581; Available from:

https://www.cambridge.org/core/journals/perspectives-onpolitics/article/testing-theories-of-american-politics-elites-i nterest-groups-and-average-citizens/62327F513959D0A30 4D4893B382B992B DOI:10.1017/s1537592714001595

[7] Branham J, Soroka SN and Wlezien C. When do the rich win? Political Sci Q [Internet]. 2017; 132(1):43-62; Available from:

http://sites.utexas.edu/government/files/2016/10/PSQ_Oct 20.pdf DOI:10.1002/polq.12577

[8] Burstein P. American public opinion, advocacy, and policy in Congress: what the public wants and what it gets. New York: Cambridge Univ. Press; 2014. 233 p.

[9] Smith KB, Larimer CW. The public policy theory primer. Boulder: Westview Press, 2016. 288 p.

[10] Wang J. Santa Fe shooting likely didn't change Texans' views on gun control, polling shows. Dallas News [Internet], 2018 May 31. Available from: https://www.dallasnews.co $\mathrm{m} /$ news/guns/2018/05/31/santa-fe-shooting-likely-didnt-ch ange-texans-views-gun-control-polling-shows

[11] Le Miere J. Trump acted like a "toddler," "kept mentioning" arming teachers, mother of Texas school shooting victim says. Newsweek [Internet], 2018 Jun 1. Available from http://www.newsweek.com/donald-trump-toddler-school-s hooting-texas-953211

[12] Edwards G, Nesson E, Robinson J and Vars F. Looking down the barrel of a loaded gun: the effect of mandatory handgun purchase delays on homicide and suicide. Econ $\mathrm{J}$ [Internet]. July 2017. Available from: https://onlinelibrary.wiley.com/doi/full/10.1111/ecoj.1256 7 DOI:10.1111/ecoj.12567 